\title{
Euphorbia dracunculoides L. abrogates carbon tetrachloride induced liver and DNA damage in rats
}

\author{
Riffat Batool ${ }^{1}$, Muhammad Rashid Khan ${ }^{{ }^{*}}$ and Muhammad Majid ${ }^{2}$
}

\begin{abstract}
Background: Evaluation of Euphorbia dracunculoides of family Euphorbiaceae during previous studies had established the in vitro antioxidant and in vivo anti-inflammatory activities. The plant is used by the local communities of Pakistan for various disorders including rheumatism and edema. In this investigation we have evaluated the hepatoprotective effects against $\mathrm{CCl}_{4}$ induced toxicity in rat.
\end{abstract}

Methods: Dry powder of the aerial parts of E. dracunculoides was extracted with $95 \%$ methanol to get the extract (EDME). To investigate the hepatoprotective effects of EDME the Sprague-Dawley male rats were divided in to 8 groups with 6 rats in each. Group I and II were the normal and vehicle treated while the Groups III-VI were injected intraperitoneally with $1 \mathrm{ml}$ of $\mathrm{CCl}_{4}$ (30\% in olive oil). Rats of Group IV were orally administered with silymarin (50 mg/kg) while the Group V and VI with $200 \mathrm{mg} / \mathrm{kg}$ and $400 \mathrm{mg} / \mathrm{kg}$ of EDME, respectively. Animals of Group VII (200 mg/kg) and VIII (400 mg/kg) were treated with EDME alone. The treatments were given thrice a week for 4 weeks. Effects of EDME were evaluated for the protective effects against oxidative stress and genotoxicity induced with $\mathrm{CCl}_{4}$ in liver of rat.

Results: Analysis of serum indicated significant $(p<0.05)$ rise in the level of aspartate transaminase (AST), alanine transaminase (ALT), alkaline phosphatase (ALP) and globulin whereas decrease was recorded for the total protein and albumin in $\mathrm{CCl}_{4}$ treated rats. In liver tissues the activity level of catalase (CAT), peroxidase (POD), superoxide dismutase (SOD), glutathione-S-transferase (GST), glutathione (GSH) was decreased while the level of lipid peroxides; thiobarbituric acid reactant substances (TBARS), nitrite and hydrogen peroxide increased in $\mathrm{CCl}_{4}$ treated rats as compared to the control group. Histopathological injuries and DNA damages were recorded in liver of rat with $\mathrm{CCl}_{4}$ treatment. However, coadministration of EDME, dose dependently, ameliorated the $\mathrm{CCl}_{4}$-induced hepatic toxicity in these parameters.

Conclusions: These results suggested that the phyto-constituents of EDME were able to ameliorate the oxidative stress induced with $\mathrm{CCl}_{4}$ and can be a useful therapeutic agent for oxidative stress related disorders.

Keywords: Euphorbia Dracunculoides, Oxidative stress, Lipid peroxidation, Genotoxicity

\section{Background}

The reactive oxygen species (ROS) and reactive nitrogen species (RNS) are produced as byproduct of metabolic pathways. The reactive species include hydrogen peroxide $\left(\mathrm{H}_{2} \mathrm{O}_{2}\right)$, hydroxyl radical $(\mathrm{OH})$, nitric oxide $(\mathrm{NO})$ and superoxide anion $\left(\mathrm{O}_{2}^{-}\right)$. Production of such species in trivial amounts is required for normal physiological functions but surplus yield can cause oxidative stress. Drugs,

\footnotetext{
* Correspondence: mrkhanqau@yahoo.com

${ }^{1}$ Department of Biochemistry, Faculty of Biological Sciences, Quaid-i-Azam University, Islamabad 45320, Pakistan

Full list of author information is available at the end of the article
}

chemicals, pollutant and radiations are the common sources for the generation of free radicals which cause damages to cellular organization by affecting membranes, proteins, lipids as well as nucleic acids $[1,2]$. Such effects have been observed in pathological conditions like diabetes mellitus, Alzheimer's disease, liver cirrhosis, rheumatic arthritis, cancer and multiple sclerosis [3, 4].

Carbon tetrachloride $\left(\mathrm{CCl}_{4}\right)$ can cause hepatotoxicity by producing oxidative stress which leads to steatosis and centrilobular necrosis and its prolonged administration produces chronic liver injury which leads to hepatic fibrosis [5]. In recent years, antioxidants have been 
isolated from plants to scavenge free radicals. Within the antioxidant compounds, flavonoids and phenolic acids have the considerable antioxidative potential [6]. The phenolic compounds show the antioxidant activity because of the presence of hydroxyl group in conjugated ring in their structure, and hence these can prevent free radical mediated diseases. Antioxidants protect the tissues by scavenging ROS [7], singlet oxygen [8] and superoxide anion [9].

Euphorbiaceae is one of the most varied family, ranges from the herb, shrub and tall tree [10]. The largest among the spurge family is the genus Euphorbia covering over 2000 species. Most of the species of this genus are used conventionally in Chinese medicinal system for curing skin disorders, edemas etc. [11]. Euphorbia dracunculoides Lam. a short-lived perennial herb attaining height up to $10-40 \mathrm{~cm}$ is dispersed in valleys, riverbanks, roadsides of filthy areas in Southwest Asia, South Europe and North Africa. It has been used as a traditional medicine in India for its diuretic and laxative effects [12]. A decoction of whole plant is effective in killing lice when applied to the body of cattle [13]. Fruits are known for their potential to exterminate warts from the skin [14]. Leaf paste mixed with powder of the black pepper and ghee is useful in snake bite whereas leaf powder is used in epilepsy [15]. Hepatoprotective effects of E. nematocypha have been investigated on hepatocyte cell lines [16] whereas in vivo investigation of E. neriifolia against $\mathrm{CCl}_{4}$ induced hepatic damages in rat has been reported by Bigoniya and Rana [17]. Aamir et al. [18] reported the hepatoprotective potential of E. thymifolia against $\mathrm{CCl}_{4}$ induced hepatic damages in rat.

The medicinal propensity can be assessed by initial qualitative phytochemical screening of plants. Evalaution of $E$. dracunculoides confirmed the presence of coumarins, terpenoids, tannins, flavonoids, phenols, saponins, alkaloids and betacyanin. GC-MS analysis of $n$-hexane extract revealed the presence of 30 chemical constituents. Analysis of aqueous extract through HPLC confirmed the presence of four compounds i.e. catechin, rutin, myricetin and caffeic acid. Catechin is a polyphenol and has excellent antioxidant potential against free radicals and provides protection against inflammation, neurological disorders and apoptosis. Rutin is a well reputed secondary metabolite of plants with admirable anti-inflammatory, hepatoprotective and antioxidant activities. Various antioxidant assays exhibited significant correlation with that of total phenolic and total flavonoids contents [19]. Non-toxic attitude with profound anti-inflammatory and antioxidant assertiveness of $E$. dracunculoides make it a strong candidate for in vivo evaluation against oxidative stress induced by $\mathrm{CCl}_{4}$ in rat. In this concern, activity of hepatic antioxidant enzymes and biochemical investigation of serum was executed. Also to check protective potential of the extract at genetic level, comet assay was conducted.

\section{Methods \\ Plant collection}

Plant material was collected in April 2015 from District Lakki Marwat, Pakistan. Then recognized by its native name and confirmed by Dr. Rizwana Aleem Qureshi, Department of Plant Sciences, Quaid-i-Azam University, Islamabad. Voucher specimen, with Accession No. 127962 was deposited at the Herbarium of Pakistan, Quaid-i-Azam, University, Islamabad, Pakistan.

\section{Preparation of extract}

The aerial part of the plant was washed to get free of dust constituents and shade dried for 3 weeks at room temperature $\left(20-25{ }^{\circ} \mathrm{C}\right)$. The fully dried plant was ground with an electric grinder. The powder $(1.2 \mathrm{~kg})$ was macerated twice at room temperature with $3 \mathrm{l}$ of $95 \%$ methanol for $48 \mathrm{~h}$. Filtrate was dried in rotary vacuum evaporator at $40{ }^{\circ} \mathrm{C}$ to obtain crude methanol extract of $E$. dracunculoides (EDME).

\section{Acute toxicity study}

Acute toxicity of EDME was investigated on SpragueDawley rats including females and males. The rats in each group were three (females 2; male 1) and were orally administered during morning (fasting conditions) with EDME at 50, 250, 500, 1000, 2000, 3000, $4000 \mathrm{mg} /$ $\mathrm{kg}$. Saline $(10 \mathrm{ml} / \mathrm{kg})$ was administered to the control rats. The animals were examined once daily for 14 days for mortality, behavioral pattern (lethargy, sleep, salivation), changes in physical appearance, injury, pain, and signs of illness.

\section{Experimental design}

The protocol of Shyu et al. [20] was trailed to do this experiment. Forty eight (48) male Sprague Dawley rats (180-200 g) were used for experiment. Guidelines of National Institute of Health, Islamabad were strictly followed in order to conduct experiment effectively. The designed protocol was ratified (Bch\#0265) by the Ethical Committee of Quaid-i-Azam University, Islamabad, Pakistan. Animals were kept at room temperature with a dark/light $12 \mathrm{~h}$ phase in ordinary cages. Animals were properly fed on usual laboratory feed and water. The arbitrarily distribution of rats was done in eight different groups and each group was treated with its respective dose or combination of doses in calculated amount. Group I was remained untreated and only standard food supply was offered. Group II labeled as vehicle control was orally administered with $10 \%$ DMSO in olive oil $(1 \mathrm{ml} / \mathrm{kg})$. Rats of Group III were intraperitoneally injected with $1 \mathrm{ml} / \mathrm{kg}$ of $30 \% \mathrm{CCl}_{4}$ (in olive oil). Animals 
of Group IV were administered with $1 \mathrm{ml} / \mathrm{kg}$ of $30 \%$ $\mathrm{CCl}_{4}$ (in olive oil) + silymarin dissolved in DMSO $(50 \mathrm{mg} / \mathrm{kg})$. Rats of group $\mathrm{V}$ and group VI were treated with $1 \mathrm{ml} / \mathrm{kg}$ of $30 \% \mathrm{CCl}_{4}$ (in olive oil) + EDME dissolved in DMSO $(200 \mathrm{mg} / \mathrm{kg}$ and $400 \mathrm{mg} / \mathrm{kg}$, respectively) whereas Group VII and VIII were administered with EDME alone dissolved in DMSO $(200 \mathrm{mg} / \mathrm{kg}$ and $400 \mathrm{mg} / \mathrm{kg}$, respectively). The treatments of $\mathrm{CCl}_{4}$ and EDME were given in the morning on alternate days thrice a week for 4 weeks. After last treatment rats were unfed for $24 \mathrm{~h}$ and were euthanized after sedation with chloroform. Blood was collected for serum analysis. The liver was excised and placed in saline solution. A part of the liver was stored in liquid nitrogen for enzymatic and biochemical studies while the other portion was stored in $10 \%$ formalin solution histopathological studies.

\section{Serum analysis}

For assessment of liver function tests, serum mockups were analyzed for AST, ALT, ALP, albumin, globulin and total protein by means of AMP diagnostic kits (Graz, Austria) according to the instructions of the manufacturer.

\section{Biochemical analysis \\ Assessment of antioxidative profile}

Tissues of liver from various groups were homogenized in $10 \mathrm{X}$ prepared by the addition of $100 \mathrm{mM}$ potassium phosphate buffer having $1 \mathrm{mM}$ EDTA (pH 7.4). Centrifugation of homogenate was done at $12000 \times$ g at $4{ }^{\circ} \mathrm{C}$ for $30 \mathrm{~min}$. In the supernatant antioxidant enzyme assays which are listed below were performed.

\section{Catalase assay (CAT)}

Catalase activity was measured by the procedure of Chance and Maehly [21]. The reaction mixture for the catalase assay contained $2500 \mu \mathrm{l}$ of phosphate buffer $(\mathrm{pH} 5.0 ; 50 \mathrm{mM}), 100 \mu \mathrm{l}$ of the supernatant and $400 \mu \mathrm{l}$ of $\mathrm{H}_{2} \mathrm{O}_{2}(5.9 \mathrm{mM})$. Change in absorbance was determined at $240 \mathrm{~nm}$ after a minute. One unit catalase activity was demarcated as an absorbance variation of 0.01 units per minute.

\section{Peroxidase assay (POD)}

Peroxidase commotion was measured by the Chance and Maehly [21] method. Reaction mixture of peroxidase assay contained $2500 \mu \mathrm{l}$ of phosphate buffer, $(\mathrm{pH} 5.0$; $50 \mathrm{mM}), 150 \mu \mathrm{l}$ of guaiacol $(20 \mathrm{mM}), 300 \mu \mathrm{l}$ of $\mathrm{H}_{2} \mathrm{O}_{2}$ $(50 \mathrm{mM})$ and $1000 \mu \mathrm{l}$ of the supernatant. Change in absorbance after a minute was recorded at $470 \mathrm{~nm}$. One unit peroxidase activity was described as an absorbance change of 0.01 units per minute.

\section{Superoxide dismutase, assay (SOD)}

SOD assay was performed by following the Kakkar et al. [22] method. The reaction mixture contained $100 \mu \mathrm{l}$ of phenazine methosulphate $(186 \mu \mathrm{M}), 1200 \mu \mathrm{l}$ of sodium pyrophosphate buffer ( $\mathrm{pH} 7.0 ; 0.052 \mathrm{mM}$ ) and $300 \mu \mathrm{l}$ of supernatant obtained from liver homogenate which was incorporated to reaction amalgam after centrifugation at $1500 \mathrm{rpm}$ for $10 \mathrm{~min}$ and then at $10000 \mathrm{rpm}$ for $15 \mathrm{~min}$. The reaction was started by adding $0.2 \mathrm{ml}$ of $\mathrm{NADH}$ $(780 \mu \mathrm{M})$ and then stopped on adding $1000 \mu \mathrm{l}$ of glacial acetic acid after $1 \mathrm{~min}$. Absorbance was recorded at $560 \mathrm{~nm}$ and results were articulated in units/mg protein.

\section{Glutathione-S-transferase assay (GST)}

GST was assessed by following Habig et al. [23] method. The reaction assortment for this assay contained $1475 \mu \mathrm{l}$ of phosphate buffer $(\mathrm{pH} 6.5 ; 0.1 \mathrm{M}), 200 \mu \mathrm{l}$ of reduced glutathione $(1 \mathrm{mM}), 25 \mu \mathrm{l}$ of $1 \mathrm{mM}$ 1-chloro-2,4-dinitrobenzene $(\mathrm{CDNB})$ and $300 \mu \mathrm{l}$ of supernatant in $2000 \mu \mathrm{l}$ of total volume. Change in absorbance was recorded at $340 \mathrm{~nm}$. The enzyme activity was calculated as nM CDNB conjugate formed per min/mg protein and the molar extinction coefficient used here was $9.6 \times 10^{-3} \mathrm{M}^{-1} \mathrm{~cm}^{-1}$.

\section{Reduced glutathione assay (GSH)}

Reduced glutathione assay was performed by the method of Jollow et al. [24]. An aliquot of $1000 \mu \mathrm{l}$ of supernatant of the homogenate was initially precipitated with $1000 \mu \mathrm{l}$ (4\%) of sulfosalicylic acid. After an hour it was centrifuged at $1200 \times \mathrm{g}$ at $4{ }^{\circ} \mathrm{C}$ for $20 \mathrm{~min}$. From the filtrate $100 \mu \mathrm{l}$ was mixed with $2700 \mu \mathrm{l}$ of phosphate buffer $(\mathrm{pH} 7.4 ; 0.1 \mathrm{M})$, and $200 \mu \mathrm{l}$ of $100 \mathrm{mM} \mathrm{1,2-dithio-bis} \mathrm{nitro-benzoic} \mathrm{acid}$ (DTNB). The absorbance of the reaction mixture was measured immediately at $412 \mathrm{~nm}$. Reduced glutathione activity was determined as $\mu \mathrm{M}$ GSH/g tissue.

\section{Lipid peroxidation (TBARS) estimation}

Lipid peroxidation assay was executed by following the protocol of Iqbal et al. [25]. The reaction mixture for this assay comprised of $580 \mu \mathrm{l}$ of phosphate buffer $(\mathrm{pH} 7.4 ; 0.1 \mathrm{M}), 200 \mu \mathrm{l}$ of supernatant of the homogenate, $20 \mu \mathrm{l}$ of ferric chloride $(100 \mathrm{mM})$ and $200 \mu \mathrm{l}$ of ascorbic acid $(100 \mathrm{mM})$ in a total $1000 \mu \mathrm{l}$ volume. The incubation of reaction mixture was executed at $37{ }^{\circ} \mathrm{C}$ in water bath for an hour. The reaction was stopped by adding $1000 \mu \mathrm{l}$ of $10 \%$ trichloroacetic acid. After the addition of $1000 \mu \mathrm{l}$ of $0.66 \%$ thiobarbituric acid, the conduits were retained for $20 \mathrm{~min}$ in boiling water and then placed on ice bath and centrifuged for $10 \mathrm{~min}$ at $2500 \times$ g. The quantity of TBARS (lipid peroxidation) was calculated by taking the absorbance of supernatant contrary to a reagent blank at $535 \mathrm{~nm}$. The results were articulated as $\mathrm{nM}$ TBARS $/ \mathrm{min} / \mathrm{mg}$ tissue at $37{ }^{\circ} \mathrm{C}$ using molar extinction coefficient of $1.56 \times 10^{-5} \mathrm{M}^{-1} \mathrm{~cm}^{-1}$. 


\section{Protein estimation}

The method of Lowry et al. [26] was followed to estimate total soluble protein of liver tissues by using bovine serum albumin (BSA) standard curve.

\section{Hydrogen peroxide assay $\left(\mathrm{H}_{2} \mathrm{O}_{2}\right)$}

Hydrogen peroxide $\left(\mathrm{H}_{2} \mathrm{O}_{2}\right)$ assay was performed by following the protocol of Pick and Keisari [27] using the principle of $\mathrm{H}_{2} \mathrm{O}_{2}$-mediated horseradish peroxidasedependent oxidation of phenol red. The reaction mixture contained $3 \mathrm{ml}$ of tissue homogenate recessed in $1000 \mu \mathrm{l}$ of $0.28 \mathrm{nM}$ of phenol red, $5.6 \mathrm{nM}$ dextrose, $0.06 \mathrm{M}$ phosphate buffer ( $\mathrm{pH} 7.0$ ) and 8.5 units of horseradish peroxidase and incubated at $37{ }^{\circ} \mathrm{C}$ for $60 \mathrm{~min}$. A volume of $10 \mu \mathrm{l}$ of $10 \mathrm{~N}$ of $\mathrm{NaOH}$ was added to stop the reaction. After centrifugation for $5 \mathrm{~min}$ at $800 \times \mathrm{g}$ the absorbance of the supernatant was measured at $610 \mathrm{~nm}$ against reagent blank. Quantity of $\mathrm{H}_{2} \mathrm{O}_{2}$ produced was given as $\mathrm{nM} \mathrm{H}_{2} \mathrm{O}_{2} / \mathrm{min} / \mathrm{mg}$ tissue by using $\mathrm{H}_{2} \mathrm{O}_{2}$ oxidized phenol red standard curve.

\section{Nitrite assay}

The procedure of Grisham et al. [28] was used to quantify nitrite contents in the samples. After homogenization of the tissue equal volume $(100 \mu \mathrm{l})$ of $0.3 \mathrm{M} \mathrm{NaOH}$ and $5 \%$ $\mathrm{ZnSO}_{4}$ was mixed for deproteinization. After centrifugation for $15-20 \mathrm{~min}$ at $6400 \times \mathrm{g}$ an aliquot of $30 \mu \mathrm{l}$ of the supernatant was mixed with $2 \mathrm{ml}$ of Griess reagent in cuvette. The absorbance was recorded at $540 \mathrm{~nm}$. Sodium nitrite curve was used for determining the nitrite amount in tissue samples.

\section{Comet assay}

DNA mutilation was evaluated by following the protocol of Dhawan et al. [29]. The slides were dipped in methanol then burned over blue flame to get rid of dust and machine oil. About three quarters of sanitized slides were immersed in $1 \%$ solution of normal melting point agarose (NMPA) and was endorsed to set at room temperature. A tiny piece of liver tissue was minced into small pieces in $1 \mathrm{ml}$ cold lysing solution. Before coating on already coated slides, the minced tissue was assorted with $85 \mu \mathrm{l}$ of low melting point agarose solution. The slide was covered gently by placing a cover slip over it and placed for 10-12 min on ice packs. For a second time low melting agarose was added on slide by removing cover slip. Then it was permitted to solidify on ice packs. After coating the slide thrice with low melting agarose, it was retained in lysing solution for $10 \mathrm{~min}$ and then in freezer for about $2 \mathrm{~h}$. After performing electrophoresis, staining was done with ethidium bromide (1\%) and examined under the fluorescent microscope. The level of DNA damage was appraised by CASP 1.2.3.b software for image analysis. In every sample almost 50-
100 cells were examined for head length, comet length, tail moment, tail length and amount of DNA in head of hepatic cell's nuclei.

\section{Histopathological study of tissues}

Alterations in histopathology were evaluated via paraffinembedded staining procedure. The multistep process entails fixation of liver samples in a fixative and were further rinsed and processed in the course of an ascending sequence of alcohol (50, 70, 90 and 100\%). The tissues were then secured on hard solid blocks via paraffin-embedding. In the final step, slides were prepared by sectioning $3-4 \mu \mathrm{m}$ thin layers of the embedded-tissue samples followed by staining with hematoxylin and eosin. Afterwards, these slides were examined under the light microscope (DIALUX $20 \mathrm{~EB})$ at 40X and photographed via HDCE-50B camera.

\section{Statistical analysis}

The values for all the assays were articulated as mean \pm standard deviation. Tukey's multiple comparison tests centered on parametric scrutiny of variance was used to appraise the enormities of altered treatments to rats in vivo by the use of computer software Statistix 8.1. Statistical significance for demeanors was done at $P$ value $\leq 0.05$.

\section{Results}

Defensive effect of EDME on liver serum enzymes

The ameliorating effects of EDME against the $\mathrm{CCl}_{4}$ induced hepatotoxicity were assessed by determining the level of ALP, AST and ALT in serum of rat (Table 1). Administration of $\mathrm{CCl}_{4}$ to rats caused a significant escalation $(p<0.05)$ in the level of ALP $=136.32 \pm 4.11 \mathrm{mg} / \mathrm{dl}$, AST $=89.3 \pm 3.26 \mathrm{mg} / \mathrm{dl}$ and ALT $=173.2 \pm 4.19 \mathrm{mg} / \mathrm{dl}$ as compared to the ALP $=64.3 \pm 3.15 \mathrm{mg} / \mathrm{dl}$, AST $=43.0 \pm 2.08 \mathrm{mg} / \mathrm{dl}$ and ALT $=44.6 \pm 2.22 \mathrm{mg} / \mathrm{dl}$ in the control group. The abnormally high level of serum markers was significantly $(p<0.05)$ decreased by coadministration of EDME $(200 \mathrm{mg} / \mathrm{kg})$ which tend to regulate these elevated levels $(p<0.05)$ in contrast to that of the control group. However, co-administration of the high dose of EDME (400 mg/kg) significantly decreased the level of these enzymes and the level obtained were as ALP $=71.7 \pm 3.39 \mathrm{mg} / \mathrm{dl}, \mathrm{AST}=53.8 \pm 2.33 \mathrm{mg} / \mathrm{dl}$ and ALT $=67.4 \pm 3.23 \mathrm{mg} / \mathrm{dl}$ in serum. The two doses of $200 \mathrm{mg} / \mathrm{kg}$ and $400 \mathrm{mg} / \mathrm{kg}$ of EDME alone did not induce any alteration $(p>0.05)$ in the level of ALP, AST and ALT of serum as compared to the control group.

\section{Defensive effect of EDME on serum protein profile}

For the evaluation of protective effects of EDME against the $\mathrm{CCl}_{4}$ induced toxicity on liver metabolism the level of albumin, globulin and total serum protein were examined (Table 1). In serum the level of albumin and total 
Table 1 Effect of EDME on biochemical markers of liver in serum

\begin{tabular}{lllllll}
\hline Treatment & $\begin{array}{l}\text { ALT } \\
(\mathrm{U} / \mathrm{l})\end{array}$ & $\begin{array}{l}\text { ALP } \\
(\mathrm{U} / \mathrm{l})\end{array}$ & $\begin{array}{l}\text { AST } \\
(\mathrm{U} / \mathrm{l})\end{array}$ & Serum proteins (mg/dl) & $\begin{array}{l}\text { Albumin } \\
(\mathrm{mg} / \mathrm{dl})\end{array}$ & $\begin{array}{l}\text { Globulin (mg/dl) } \\
\text { Control }\end{array}$ \\
$44.6 \pm 2.22^{\mathrm{e}}$ & $64.3 \pm 3.15^{\mathrm{d}}$ & $43.0 \pm 2.08^{\mathrm{d}}$ & $8.5 \pm 0.37^{\mathrm{a}}$ & $5.6 \pm 0.2^{\mathrm{a}}$ & $2.9 \pm 0.24^{\mathrm{c}}$ \\
Vehicle Control & $44.97 \pm 2.16^{\mathrm{e}}$ & $63.8 \pm 2.12^{\mathrm{d}}$ & $43.3 \pm 2.25^{\mathrm{d}}$ & $8.9 \pm 0.40^{\mathrm{a}}$ & $5.5 \pm 0.23^{\mathrm{a}}$ & $3.0 \pm 0.26^{\mathrm{bc}}$ \\
$\mathrm{CCl}_{4} 1 \mathrm{ml} / \mathrm{kg}$ & $173.2 \pm 4.19^{\mathrm{a}}$ & $136.3 \pm 4.11^{\mathrm{a}}$ & $89.3 \pm 3.26^{\mathrm{a}}$ & $5.6 \pm 0.15^{\mathrm{d}}$ & $2.1 \pm 0.18^{\mathrm{d}}$ & $3.5 \pm 0.16^{\mathrm{a}}$ \\
$\mathrm{CCl}_{4}+$ Sily $50 \mathrm{mg} / \mathrm{kg}$ & $61.8 \pm 3.29^{\mathrm{d}}$ & $71.6 \pm 2.41^{\mathrm{c}}$ & $48.0 \pm 1.15^{\mathrm{e}}$ & $7.5 \pm 0.19^{\mathrm{b}}$ & $4.3 \pm 0.19^{\mathrm{b}}$ & $3.2 \pm 0.13^{\mathrm{b}}$ \\
$\mathrm{CCl}_{4}+\mathrm{EDME} 200 \mathrm{mg} / \mathrm{kg}$ & $104.2 \pm 3.21^{\mathrm{b}}$ & $93.1 \pm 3.22^{\mathrm{b}}$ & $67.1 \pm 2.09^{\mathrm{b}}$ & $6.3 \pm 0.22^{\mathrm{c}}$ & $3.5 \pm 0.15^{\mathrm{c}}$ & $2.8 \pm 0.17^{\mathrm{c}}$ \\
$\mathrm{CCl}_{4}+\mathrm{EDME} 400 \mathrm{mg} / \mathrm{kg}$ & $67.4 \pm 3.23^{\mathrm{c}}$ & $71.7 \pm 3.39^{\mathrm{c}}$ & $53.8 \pm 2.33^{\mathrm{c}}$ & $7.7 \pm 0.24^{\mathrm{b}}$ & $4.7 \pm 0.42^{\mathrm{b}}$ & $3.0 \pm 0.18^{\mathrm{bc}}$ \\
EDME $200 \mathrm{mg} / \mathrm{kg}$ & $46.2 \pm 2.16^{\mathrm{e}}$ & $65.8 \pm 3.13^{\mathrm{d}}$ & $45.3 \pm 2.15^{\mathrm{d}}$ & $8.7 \pm 0.16^{\mathrm{a}}$ & $5.8 \pm 0.20^{\mathrm{a}}$ & $2.9 \pm 0.12^{\mathrm{c}}$ \\
EDME $400 \mathrm{mg} / \mathrm{kg}$ & $45.7 \pm 2.31^{\mathrm{e}}$ & $62.32 \pm 3.17^{\mathrm{d}}$ & $43.3 \pm 1.28^{\mathrm{d}}$ & $8.8 \pm 0.21^{\mathrm{a}}$ & $5.7 \pm 0.29^{\mathrm{a}}$ & $3.1 \pm 0.14^{\mathrm{bc}}$ \\
\hline
\end{tabular}

Mean \pm SD $(n=6)$, Means with different superscript letters in a column specify significance at $p<0.05$

EDME Euphorbia dracunculoides methanol extract, Sily silymarin, $\mathrm{CCl}_{4}$ Carbon tetrachloride

protein decreased $(p<0.05)$ while the level of globulin increased with $\mathrm{CCl}_{4}$ toxicity in rats as compared to the control group (Table 1). The results showed that EDME have significant protective effects and the altered level of albumin, total protein and globulin induced with $\mathrm{CCl}_{4}$ were improved after co-administration of EDME in a dose dependent manner. The protective effects of silymarin for albumin, globulin and total protein were comparable $(p>0.05)$ with the higher dose of EDME $400 \mathrm{mg} / \mathrm{kg}$ to rats. Treatment of rats with EDME alone did not $(p>0.05)$ change the level of protein profile as compared to the control group.

\section{Defensive effect of EDME on liver antioxidant enzymes}

Table 2 evaluates the activity level of SOD, CAT, POD and GST in liver homogenates. A significant $(p<0.05)$ decline in the activity of CAT, SOD, POD and GST was observed in liver homogenates of $\mathrm{CCl}_{4}$ treated group as compared to the control group. The activity level of CAT, POD, SOD and GST of liver homogenates in $\mathrm{CCl}_{4}$ treated group were $1.86 \pm 0.12 \mathrm{U} / \mathrm{min}, 3.93 \pm 0.23 \mathrm{U} /$ $\mathrm{min}, 1.12 \pm 0.16 \mathrm{U} / \mathrm{mg}$ protein and $8.94 \pm 0.92 \mathrm{nM} / \mathrm{min} /$ mg protein, respectively. A dose dependent increase in the activity level of CAT, POD, SOD and GST of liver homogenates was recorded with co-administration of EDME. Co-administration of rats with low dose of EDME $(200 \mathrm{mg} / \mathrm{kg})$ ameliorated the toxicity of $\mathrm{CCl}_{4}$ and increased the activity level of CAT, POD, SOD and GST with values noted as $2.48 \pm 0.14 \mathrm{U} / \mathrm{min}, 4.75 \pm 0.35 \mathrm{U} /$ $\mathrm{min}, 1.78 \pm 0.21 \mathrm{U} / \mathrm{mg}$ and $16.26 \pm 1.07 \mathrm{nM} / \mathrm{min} / \mathrm{mg}$ protein, respectively. Higher dose of EDME $(400 \mathrm{mg} / \mathrm{kg}$ ) exhibited more protective effects and the activity level recorded were $4.05 \pm 0.29 \mathrm{U} / \mathrm{min}, 6.56 \pm 0.72 \mathrm{U} / \mathrm{min}$, $2.46 \pm 0.16 \mathrm{U} / \mathrm{mg}$ protein and $19.87 \pm 2.17 \mathrm{nM} / \mathrm{min} / \mathrm{mg}$ protein, respectively. Administration of silymarin to $\mathrm{CCl}_{4}$ intoxicated rats significantly $(p<0.05)$ increased the level of antioxidant enzyme profile except the SOD as compared to the higher dose of EDME $400 \mathrm{mg} / \mathrm{kg}$ administered to rats. However, EDME treatment to rats alone at $400 \mathrm{mg} / \mathrm{kg}$ did not affect $(p>0.05)$ the enzymatic level as compared to the of control group.

\section{Defensive effect of EDME on liver biochemicals}

Antioxidant efficacy of EDME was further assessed by determining the concentration of soluble proteins, GSH, TBARS, nitrite and $\mathrm{H}_{2} \mathrm{O}_{2}$ in liver samples of rats (Table 3). Results of $\mathrm{CCl}_{4}$ injection to rats showed significant $(p<0.05)$ decrease in the level of soluble protein and GSH

Table 2 Effect of EDME antioxidant enzymes of liver

\begin{tabular}{lllll}
\hline Treatment & $\begin{array}{l}\text { CAT } \\
(\mathrm{U} / \mathrm{min})\end{array}$ & $\begin{array}{l}\text { POD } \\
(\mathrm{U} / \mathrm{min})\end{array}$ & $\begin{array}{l}\text { SOD } \\
(\mathrm{U} / \mathrm{mg} \text { protein) }\end{array}$ & $\begin{array}{l}\text { GST } \\
(\mathrm{nM} / \mathrm{min} / \mathrm{mg} \mathrm{protein})\end{array}$ \\
\hline Control & $5.47 \pm 0.21^{\mathrm{a}}$ & $8.66 \pm 1.21^{\mathrm{a}}$ & $3.28 \pm 0.17^{\mathrm{a}}$ & $21.33 \pm 2.13^{\mathrm{a}}$ \\
Vehicle control & $5.43 \pm 0.18^{\mathrm{a}}$ & $8.61 \pm 1.16^{\mathrm{a}}$ & $3.25 \pm 0.28^{\mathrm{a}}$ & $21.04 \pm 2.38^{\mathrm{a}}$ \\
$\mathrm{CCl}_{4} 1 \mathrm{ml} / \mathrm{kg}$ & $1.86 \pm 0.12^{\mathrm{e}}$ & $3.93 \pm 0.23^{\mathrm{e}}$ & $1.12 \pm 0.16^{\mathrm{e}}$ & $8.94 \pm 0.92^{\mathrm{d}}$ \\
$\mathrm{CCl}_{4}+$ Sily $50 \mathrm{mg} / \mathrm{kg}$ & $4.41 \pm 0.26^{\mathrm{b}}$ & $7.89 \pm 1.29^{\mathrm{b}}$ & $2.73 \pm 0.28^{\mathrm{b}}$ & $21.3 \pm 1.33^{\mathrm{a}}$ \\
$\mathrm{CCl}_{4}+\mathrm{EDME} 200 \mathrm{mg} / \mathrm{kg}$ & $2.48 \pm 0.14^{\mathrm{d}}$ & $4.75 \pm 0.35^{\mathrm{d}}$ & $1.78 \pm 0.21^{\mathrm{d}}$ & $16.26 \pm 1.07^{\mathrm{c}}$ \\
$\mathrm{CCl}_{4}+\mathrm{EDME} 400 \mathrm{mg} / \mathrm{kg}$ & $4.05 \pm 0.29^{\mathrm{c}}$ & $6.56 \pm 0.72^{\mathrm{c}}$ & $2.46 \pm 0.16^{\mathrm{c}}$ & $19.87 \pm 2.17^{\mathrm{b}}$ \\
EDME $200 \mathrm{mg} / \mathrm{kg}$ & $5.46 \pm 0.25^{\mathrm{a}}$ & $8.63 \pm 0.92^{\mathrm{a}}$ & $3.26 \pm 0.22^{\mathrm{a}}$ & $21.32 \pm 2.19^{\mathrm{a}}$ \\
EDME $400 \mathrm{mg} / \mathrm{kg}$ & $5.38 \pm 0.32^{\mathrm{a}}$ & $8.37 \pm 0.87^{\mathrm{a}}$ & $3.31 \pm 0.31^{\mathrm{a}}$ & $21.26 \pm 2.45^{\mathrm{a}}$ \\
\hline
\end{tabular}

Mean \pm SD $(n=6)$, Means with different superscript letters in a column specify significance at $p<0.05$ 
in the liver samples as compared to the control group. The co-treatment of EDME with $\mathrm{CCl}_{4}$, dose dependently, elevated the protein and GSH content of liver samples in contrary to the group administered with $\mathrm{CCl}_{4}$ alone. However, treatment of EDME alone to the rats exhibited non significant $(p>0.05)$ alteration in the protein and GSH content as compared to the control group.

After the completion of treatment, in the liver samples of $\mathrm{CCl}_{4}$ intoxicated rats an escalation in the content of TBARS, $\mathrm{H}_{2} \mathrm{O}_{2}$ and nitrite was recorded i.e. $44.52 \pm 3.26 \mathrm{nM} / \mathrm{min} / \mathrm{mg}$ protein, $0.77 \pm 0.19 \mu \mathrm{M} / \mathrm{ml}$ and $92.96 \pm 3.17 \mu \mathrm{M} / \mathrm{ml}$, respectively (Table 3 ). The toxicity of $\mathrm{CCl}_{4}$ was ameliorated by the co-administration of EDME in a dose dependent fashion. The level of TBARS, $\mathrm{H}_{2} \mathrm{O}_{2}$ and nitrite in liver samples of rat with co-treatment of the lower dose of EDME $200 \mathrm{mg} / \mathrm{kg}$ were; $36.87 \pm 2.38 \mathrm{nM} / \mathrm{min} / \mathrm{mg}$ protein, $0.58 \pm 0.07 \mu \mathrm{M} / \mathrm{ml}$ and $73.47 \pm 3.2 \mu \mathrm{M} / \mathrm{ml}$, respectively. The high dose of EDME $400 \mathrm{mg} / \mathrm{kg}$ remarkably $(p<0.05)$ lowered the level of TBARS, $\mathrm{H}_{2} \mathrm{O}_{2}$ and nitrite content; $28.13 \pm 2.07 \mathrm{nM} / \mathrm{min} / \mathrm{mg}$ protein, $0.44 \pm 0.07 \mu \mathrm{M} / \mathrm{ml}$ and $60.23 \pm 3.24 \mu \mathrm{M} / \mathrm{ml}$, respectively. Moreover, the rats treated with EDME alone did not exhibit alteration in the level of TBARS, $\mathrm{H}_{2} \mathrm{O}_{2}$ and nitrite in liver samples as compared to the control group.

\section{Comet assay}

Oxidative stress induced with $\mathrm{CCl}_{4}$ in rat displayed extensive DNA damages in the hepatocytes (Fig. 1). Comet parameters such as comet length, tail length, \%DNA in tail and tail moment significantly $(p<0.05)$ increased in the hepatocyte of $\mathrm{CCl}_{4}$ treated rats as compared to the control group (Table 4). However, head length and \%DNA in head decreased in hepatocyte of $\mathrm{CCl}_{4}$ treated rats as compared to the control group. In case of $\mathrm{CCl}_{4}$ treated rats $22.63 \%$ of DNA has migrated from head in the tail of comet. Genotoxicity induced with $\mathrm{CCl}_{4}$ in hepatocytes of rat decreased with co-administration of EDME to rats in a dose dependent manner. Administration of EDME $200 \mathrm{mg} / \mathrm{kg}$ and $400 \mathrm{mg} / \mathrm{kg}$ along with
$\mathrm{CCl}_{4}$ to rats have displayed potent protective effects and a substantial $(p<0.05)$ decrease in comet length, comet tail, \%DNA in tail and tail moment was exhibited in hepatocytes as compared to the $\mathrm{CCl}_{4}$ treated group. Further, EDME co-administration to rats increased the head length and \%DNA in head of comet of hepatocytes as compared to the $\mathrm{CCl}_{4}$ treated group. At lower dose of EDME $(200 \mathrm{mg} / \mathrm{kg})$ about $9.75 \%$ DNA has migrated while at the higher dose of EDME $(400 \mathrm{mg} / \mathrm{kg}) 5.07 \%$ DNA has migrated from head in the tail of comet. Coadministration of silymarin also remarkably $(p<0.05)$ restored the comet parameters in hepatocytes of $\mathrm{CCl}_{4}$ intoxicated rats. Migration of DNA from head to tail of comet with silymarin was very low $(0.94 \%)$. The administration of EDME alone did not cause any migration of DNA from head to tail of comet of hepatocytes.

\section{Defensive effect of EDME on histoarchitecture of liver}

The histopathological investigations endorsed protective effects of EDME on the biochemical studies (Fig. 2). The control group displayed normal morphology with typical central vein, kupfer cells, hepatocytes and sinusoids as shown in Fig. $2 \mathrm{a}$ and b. Administration of $\mathrm{CCl}_{4}$ caused noticeable elevation in fatty changes, inflammatory cells infiltrations, cellular hypertrophy, ballooning, dilation of central vein as shown in Fig. 2c. Treatment with reference drug silymarin $(200 \mathrm{mg} / \mathrm{kg})$ attenuated the cellular changes and disruptions as described in Fig. 2d. Administration of low dose of EDME (200 mg/ $\mathrm{kg}$ ) had lessened the hepatic injuries while high dose of EDME $(400 \mathrm{mg} / \mathrm{kg}$ ) potently preserved the typical morphology of liver (Fig. 2e and $\mathrm{f}$ ). Administration of EDME alone depicted the normal histopatholohy of the liver samples (Fig. $2 \mathrm{~g}$ and h).

\section{Discussion}

Traditional consumption of plants as medicines is considered non-damaging since centuries. To check the new promising natural antioxidants in plants or to exploit new drug development for tissue related human and

Table 3 Effect of EDME biochemical parameters in liver

\begin{tabular}{llllll}
\hline Treatment & Protein $(\mu \mathrm{g} / \mathrm{mg}$ tissue) & $\begin{array}{l}\mathrm{GSH} \\
(\mathrm{nM} / / \mathrm{min} / \mathrm{mg} \text { protein) }\end{array}$ & TBARS (nM/min/mg protein) & $\begin{array}{l}\mathrm{H}_{2} \mathrm{O}_{2} \\
(\mu \mathrm{m} / \mathrm{mg} \text { tissue })\end{array}$ & $\begin{array}{l}\text { Nitrite } \\
(\mu \mathrm{M} / \mathrm{ml})\end{array}$ \\
\hline Control & $2.55 \pm 0.14^{\mathrm{a}}$ & $19.35 \pm 1.18^{\mathrm{a}}$ & $22.33 \pm 2.12^{\mathrm{d}}$ & $0.23 \pm 0.06^{\mathrm{e}}$ & $50.61 \pm 2.13^{\mathrm{e}}$ \\
Vehicle control & $2.41 \pm 0.05^{\mathrm{ab}}$ & $19.03 \pm 1.11^{\mathrm{a}}$ & $22.07 \pm 2.1^{\mathrm{d}}$ & $0.24 \pm 0.05^{\mathrm{e}}$ & $50.93 \pm 2.15^{\mathrm{e}}$ \\
$\mathrm{CCl}_{4} 1 \mathrm{ml} / \mathrm{kg}$ & $0.98 \pm 0.08^{\mathrm{d}}$ & $6.75 \pm 0.57^{\mathrm{e}}$ & $44.52 \pm 3.26^{\mathrm{a}}$ & $0.77 \pm 0.19^{\mathrm{a}}$ & $92.96 \pm 3.17^{\mathrm{a}}$ \\
$\mathrm{CCl}_{4}+$ Sily $50 \mathrm{mg} / \mathrm{kg}$ & $2.43 \pm 0.23^{\mathrm{ab}}$ & $18.33 \pm 1.08^{\mathrm{b}}$ & $29.28 \pm 2.08^{\mathrm{c}}$ & $0.27 \pm 0.08^{\mathrm{d}}$ & $55.03 \pm 2.07^{\mathrm{c}}$ \\
$\mathrm{CCl}_{4}+\mathrm{EDME} 200 \mathrm{mg} / \mathrm{kg}$ & $1.66 \pm 0.29^{\mathrm{c}}$ & $9.33 \pm 1.18^{\mathrm{d}}$ & $36.87 \pm 2.38^{\mathrm{b}}$ & $0.58 \pm 0.07^{\mathrm{b}}$ & $73.47 \pm 3.2^{\mathrm{b}}$ \\
$\mathrm{CCl}_{4}+\mathrm{EDME} 400 \mathrm{mg} / \mathrm{kg}$ & $2.11 \pm 0.06^{\mathrm{b}}$ & $14.82 \pm 1.33^{\mathrm{c}}$ & $28.13 \pm 2.07^{\mathrm{c}}$ & $0.44 \pm 0.07^{\mathrm{c}}$ & $60.23 \pm 3.24^{\mathrm{d}}$ \\
EDME $200 \mathrm{mg} / \mathrm{kg}$ & $2.47 \pm 0.11^{\mathrm{a}}$ & $20.24 \pm 2.13^{\mathrm{a}}$ & $23.09 \pm 2.2^{\mathrm{d}}$ & $0.27 \pm 0.05^{\mathrm{e}}$ & $50.62 \pm 2.21^{\mathrm{e}}$ \\
EDME $400 \mathrm{mg} / \mathrm{kg}$ & $2.52 \pm 0.16^{\mathrm{a}}$ & $20.33 \pm 1.37^{\mathrm{a}}$ & $22.67 \pm 2.43^{\mathrm{d}}$ & $0.24 \pm 0.03^{\mathrm{e}} 51.69 \pm 2.18^{\mathrm{e}}$ \\
\hline
\end{tabular}

Mean \pm SD $(n=6)$, Means with different superscript letters in a column specify significance at $p<0.05$ 

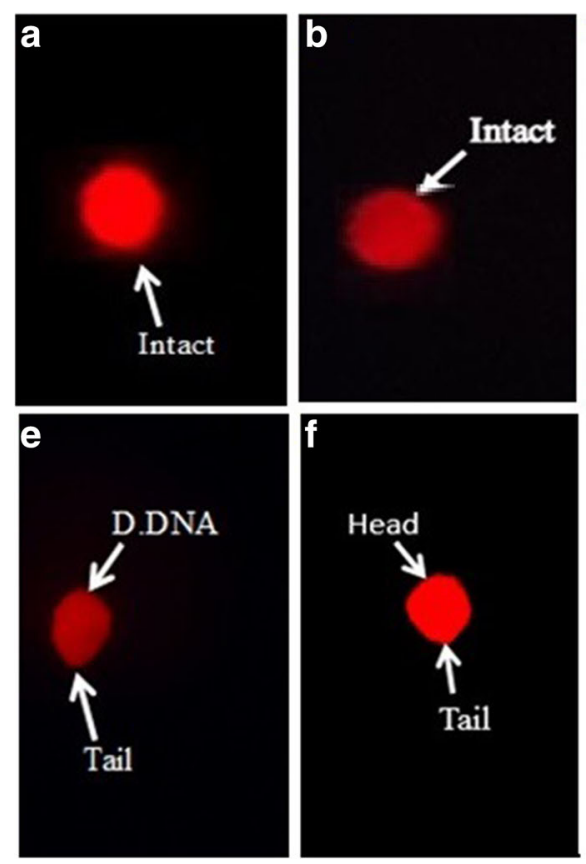

Fig. 1 Fluorescence photomicrograph of the protective effects of E. dracunculoides methanol extract on DNA damages of liver cells a Control group, b Vehicle control, c CCl $1 \mathrm{ml} / \mathrm{kg}_{4} \mathbf{d} \mathrm{CCl}_{4}+$ Silymarin $(50 \mathrm{mg} / \mathrm{kg})$, e CCl $\mathrm{CC}_{4}+\mathrm{EDME}(200 \mathrm{mg} / \mathrm{kg}), \mathbf{f} \mathrm{CCl} 4+\mathrm{EDME}(400 \mathrm{mg} / \mathrm{kg}), \mathbf{g ~ E D M E}$ (200 mg/kg), h EDME (400 mg/kg)

animal health, $\mathrm{CCl}_{4}$ was used as chemical toxicant for different organs to produce ROS which cause disturbance in the antioxidant system. The current research was conducted to check the defensive prospective of $E$. dracunculoides methanol extract on liver against oxidative stress induced by $\mathrm{CCl}_{4}$.

Determination of enzymes such as AST, ALT and AST in the serum provides an important indicator of the hepatic membrane functional integrity. In the present study, elevated levels of liver serum markers ALT, ALP and AST might reflect the hepatic damages due to $\mathrm{CCl}_{4}$ intoxication in rats. Enhanced generation of ROS in hepatocytes lead to cellular death due to DNA damage, protein oxidation, lipid peroxidation and also added to
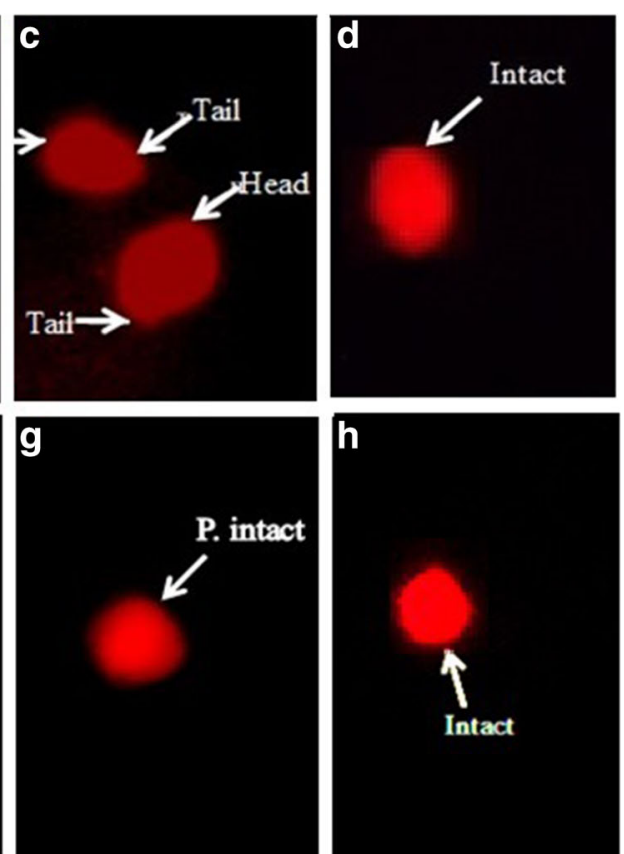

Table 4 Effect of EDME on DNA damages of liver cells by comet assay

\begin{tabular}{|c|c|c|c|c|c|c|}
\hline Group & Comet length $(\mu \mathrm{m})$ & Head length $(\mu \mathrm{m})$ & Tail length $(\mu \mathrm{m})$ & \%DNA in head & $\%$ DNA in tail & Tail moment \\
\hline Control & $42.3 \pm 1.3^{d}$ & $37.6 \pm 1.3^{a}$ & $4.2 \pm 1.2^{d}$ & $95.3 \pm 1.1^{a}$ & $4.13 \pm 0.31^{d}$ & $0.17 \pm 0.08^{e}$ \\
\hline Vehicle control & $41.6 \pm 1.94^{\mathrm{d}}$ & $37.1 \pm 0.8^{a}$ & $4.87 \pm 0.7^{d}$ & $94.18 \pm 0.9^{a}$ & $5.32 \pm 0.26^{d}$ & $0.25 \pm 0.09^{e}$ \\
\hline $\mathrm{CCl}_{4} 1 \mathrm{ml} / \mathrm{kg}$ & $64.5 \pm 1.4^{\mathrm{a}}$ & $23.4 \pm 1.2^{d}$ & $40.81 \pm 0.8^{a}$ & $73.9 \pm 1.13^{d}$ & $25.7 \pm 1^{a}$ & $10.48 \pm 0.6^{\mathrm{a}}$ \\
\hline $\mathrm{CCl}_{4}+$ Sily $50 \mathrm{mg} / \mathrm{kg}$ & $41.9 \pm 1^{d}$ & $35.2 \pm 1.78^{b}$ & $6.0 \pm 1.19^{d}$ & $94.9 \pm 0.7^{a}$ & $5.03 \pm 0.5^{d}$ & $0.30 \pm 0.07^{d}$ \\
\hline $\mathrm{CCl}_{4}+\mathrm{EDME} 200 \mathrm{mg} / \mathrm{kg}$ & $53.7 \pm 1.8^{b}$ & $32.8 \pm 1.4^{c}$ & $19.7 \pm 1.7^{b}$ & $86.5 \pm 1.2^{c}$ & $13.43 \pm 0.7^{b}$ & $2.64 \pm 0.14^{b}$ \\
\hline $\mathrm{CCl}_{4}+\mathrm{EDME} 400 \mathrm{mg} / \mathrm{kg}$ & $48.3 \pm 1.21^{\mathrm{C}}$ & $35.9 \pm 1.1^{b}$ & $11.63 \pm 1^{c}$ & $89.6 \pm 0.8^{b}$ & $10.16 \pm 0.9^{c}$ & $1.18 \pm 0.16^{c}$ \\
\hline EDME $200 \mathrm{mg} / \mathrm{kg}$ & $42.5 \pm 1.4^{d}$ & $37.4 \pm 0.9^{a}$ & $5.1 \pm 0.5^{d}$ & $94.92 \pm 1.2^{a}$ & $5.06 \pm 0.8^{d}$ & $0.25 \pm 0.09^{e}$ \\
\hline EDME 400 mg/kg & $41.1 \pm 1.53^{d}$ & $37.9 \pm 1.87^{a}$ & $3.3 \pm 0.4^{d}$ & $95.71 \pm 0.6^{a}$ & $4.27 \pm 0.5^{d}$ & $0.14 \pm 0.08^{e}$ \\
\hline
\end{tabular}

Mean \pm SD $(n=6)$, Means with different superscript letters in a column specify significance at $p<0.05$

EDME Euphorbia dracunculoides methanol extract, Sily silymarin, $\mathrm{CCl}_{4}$ Carbon tetrachloride

the hepatic damaging action [30]. Co-administration of silymarin along with $\mathrm{CCl}_{4}$ displayed the protective ability and the values of ALT, ALP and AST were found near to the level of control group. The methanol extract of plant showed its protective aptitude against the $\mathrm{CCl}_{4}$ induced hepatotoxicity in rat in a dose dependent fashion. The lower dose $(200 \mathrm{mg} / \mathrm{kg}$ ) of EDME exerted protective aptitude and the lower level of ALT, ALP and AST was recorded whereas the higher dose of EDME $(400 \mathrm{mg} / \mathrm{kg})$ exhibited potent toxico-suppressive effects and the level of above parameters was found near to the level of control animals. The elevated level of ALP, AST and ALT in serum with $\mathrm{CCl}_{4}$ treatment might be associated with membrane damage of liver cells. Restoration of the 


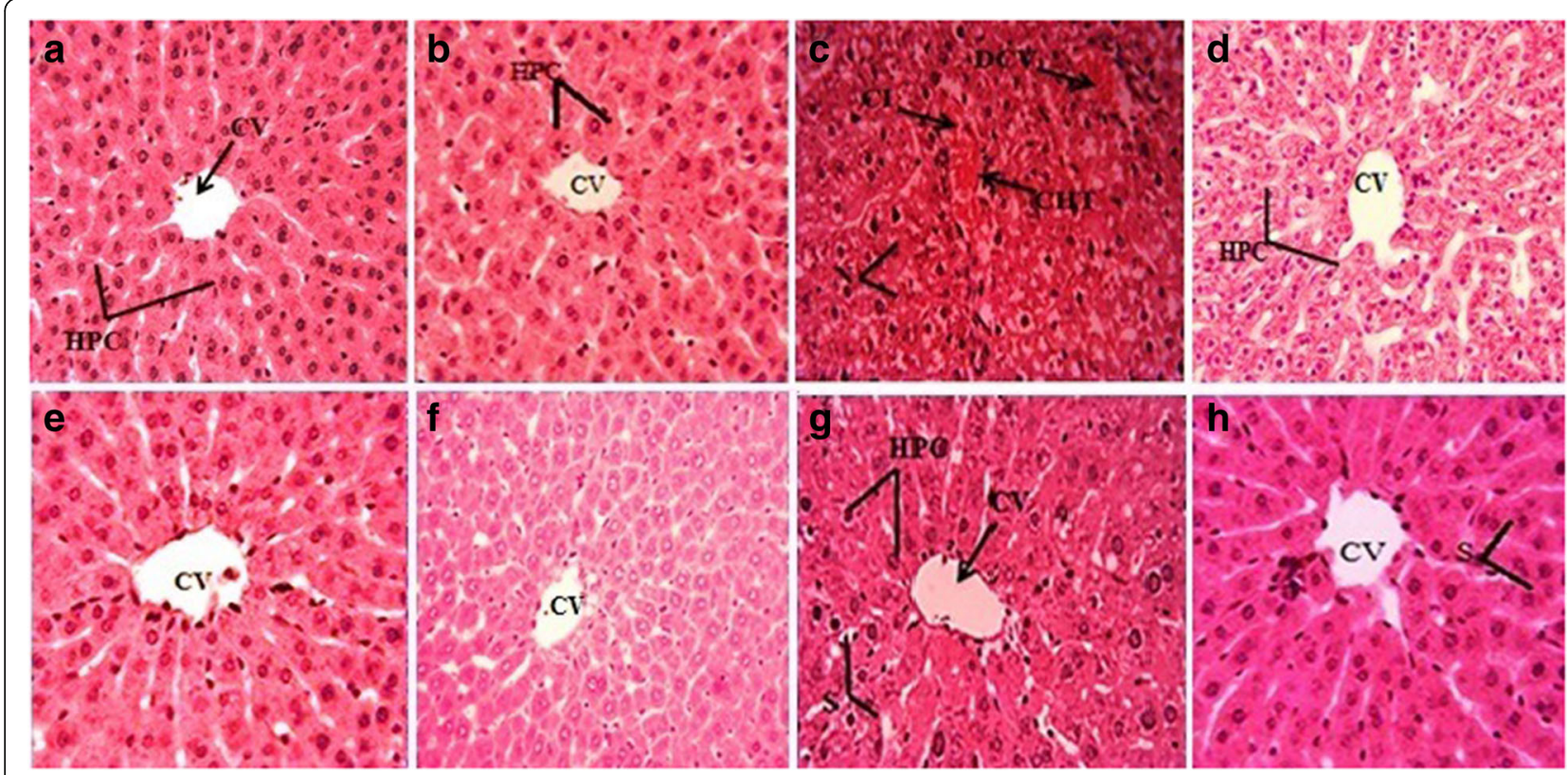

Fig. 2 40X Hematoxylin-eosin stain. Histopathological observations for the protective potential of E. dracunculoides methanol extract on liver in rat. a Control; b Vehicle control; c CCl treated; $\mathbf{d} \mathrm{CCl}_{4}+$ Silymarin $(50 \mathrm{mg} / \mathrm{kg}) ; \mathbf{e} C \mathrm{CCl}_{4}+\mathrm{EDME}(200 \mathrm{mg} / \mathrm{kg}) ; \mathbf{f} C \mathrm{CCl}_{4}+\mathrm{EDME}(400 \mathrm{mg} / \mathrm{kg}) ; \mathbf{g} \mathrm{EDME}$ (200 mg/kg); h EDME (400 mg/kg). CV-Central vein, HPC-Hepatocytes, S-Sinosides, DCV-damaged central vein, N-necrosis, CHT-cellular hypertrophy, Cl-Cellular infiltration. EDME- Euphorbia dracunculoides methanol extract

hepatic enzymes towards the control level with EDME indicated the hepatoprotective potential of the extract $[30,31]$.

On the other hand a marked decline in the level of total proteins and albumin while increase of globulin in serum of $\mathrm{CCl}_{4}$ treated group was determined in this study. Presence of albumin and globulin in normal range is essential for the proper physiology of a person. Globulin helps to regulate the function of the circulatory system. Globulins consist of four proteins; alpha-1, alpha-2, beta and gamma globulin and among them liver produces predominantly the alpha and beta globulins. Increase in the level of globulin in serum might be due to the prolong treatment of $\mathrm{CCl}_{4}$ to rat. Elevated level of globulin in serum can be considered a reliable noninvasive marker towards the degree of liver fibrosis [32]. Co-treatment with low dose of the EDME $(200 \mathrm{mg} / \mathrm{kg})$ was protective and revert the levels of serum proteins towards the control samples while the higher dose $(400 \mathrm{mg} / \mathrm{kg}$ ) showed more promising results and restored serum proteins to levels that are analogous to the control group. The protective abilities of EDME might be attributed by the presence of antioxidant phytoconstituents [19].

Antioxidant defense system includes the enzymatic antioxidants (CAT, POD, SOD, GST and GSH) which have vital role in defense system. Catalase (CAT) is a very important enzyme which can neutralize $\mathrm{H}_{2} \mathrm{O}_{2}$ through catalytic conversion to $\mathrm{H}_{2} \mathrm{O}$ and $\mathrm{O}_{2}$ at higher concentrations or through peroxidation activity at lower concentration. SOD enzyme dismutates the superoxide anion radical to less toxic $\mathrm{O}_{2}$ and $\mathrm{H}_{2} \mathrm{O}_{2}$ by oxidation reduction mechanism of its active metal ion. Glutathione peroxidase (POD) is involved in the catalytic reduction of $\mathrm{H}_{2} \mathrm{O}_{2}$ and lipid peroxides at the expenditure of glutathione. GSH is a free radical scavenger and shielded the toxic effects of various peroxides. During oxidative stress the level of these antioxidants is compromised. In the present study, $\mathrm{CCl}_{4}$ injection to rats showed the reduced levels of CAT, POD, SOD, GST and GSH. This condition might reflect the excessive generation of ROS which inhibit the synthesis of antioxidant enzymes. Decreased level of GSH might be due to its more consumption by the hepatocytes in scavenging toxic radicals generated by $\mathrm{CCl}_{4}$. Younis et al. [33] also reported the reduced levels of all above enzymes and GSH content in liver tissue by $\mathrm{CCl}_{4}$ administration. The antioxidant effects of EDME might improves the levels of antioxidant enzymes including CAT, POD, SOD and GST, and GSH that was declined due to $\mathrm{CCl}_{4}$ action. Presence of flavonoids, tannins, sterols, terpenoids might be suspected for the attribution of antioxidant activities [19]. The same study indicated the presence of strong antioxidant phytoconstituents i.e. rutin, myricetin, catechin and caffeic acid in E. dracunculoides [19]. Similar protective effects comments were also reported by using Alnus nitida against $\mathrm{CCl}_{4}$ induced oxidative stress in liver [34]. Presence of various polyphenols in the extract might be 
responsible for the scavenging of free radicals and in the inhibition of lipid peroxidation [35]. Different studies have also reported protective effects of various plant extracts against the $\mathrm{CCl}_{4}$ induced hepatic damages in rat $[17,18,31]$.

$\mathrm{CCl}_{4}$ also exerts its toxic effects by changing the level of TBARS, $\mathrm{H}_{2} \mathrm{O}_{2}$, tissue protein and nitrite content. In $\mathrm{CCl}_{4}$ intoxication the tissue protein level decreases but there is noteworthy increase in the lipid peroxidation (TBARS), $\mathrm{H}_{2} \mathrm{O}_{2}$ and nitrite content. Concentration and duration of $\mathrm{CCl}_{4}$ treatments to experimental animals exhibit varied pattern of oxidative injuries. Administration of $\mathrm{CCl}_{4}$ for short duration to rat regulates the endogenous expression of interleukin (IL)-6 and IL-10 which in turn suppresses the synthesis of tumor necrosis factor$\beta 1$ (TGF- $\beta 1$ ) and consequently inhibits the synthesis of collagen. However, longer duration of the treatment of mice with $\mathrm{CCl}_{4}$ causes the infiltration of neutrophils and fibrosis of liver [36, 37]. Parola and Robino [38] elaborated that peroxidation of lipids induce overexpression of fibrogenic cytokines by stimulating the synthesis of collagen and activating hepatic stellate cells. It might be assumed that that long term administration of $\mathrm{CCl}_{4}$ to rats might increase the oxidative stress and consequently the hepatic fibrosis. In this study hepatic histopathology of rats treated with $\mathrm{CCl}_{4}$ exhibited macro steatosis in hepatocytes of rat. Co-administration of silymarin to rats diminished the $\mathrm{CCl}_{4}$ toxic effects and showed the level of TBARS, $\mathrm{H}_{2} \mathrm{O}_{2}$ and nitrite content of liver near to the level of control rats. Administration of EDME to $\mathrm{CCl}_{4}$ intoxicated rats decrease the level of TBARS, $\mathrm{H}_{2} \mathrm{O}_{2}$ and nitrite content of liver homogenates and the level of above parameters lies near the level of control group. Our findings are supported by the work of Sajid et al. [34] who reported the in vivo antioxidant effects of Alnus nitida in rat liver intoxicated with $\mathrm{CCl}_{4}$.

Oxidative stress induced with $\mathrm{CCl}_{4}$ in liver causes the single stranded or the double stranded break in the DNA and damages the DNA integrity [39]. In the present study, comet assay was performed to check the DNA damage in terms of comet length, head length, \%DNA in head, tail length, \%DNA in tail and tail moment. A noteworthy elevation in comet length, tail length, tail moment while sharp decline in the level of DNA in head of comet was observed in the hepatocyte of $\mathrm{CCl}_{4}$ intoxicated rats in comparison to control group. DNA damages induced with $\mathrm{CCl}_{4}$ toxicity in liver has tremendously contributed towards the migration of DNA (22.63\%) from head to the tail that consequently resulted in the increase of tail length, \%DNA in tail and in tail moment of hepatocytes [39]. Oxidative damage caused by $\mathrm{CCl}_{4}$ to DNA in the hepatic cells of rat has also been reported in previous study [39]. Coadministration of EDME, dose dependently, lessened the toxic effects of $\mathrm{CCl}_{4}$ on DNA damages. Coadministration of EDME causes an increase in head length and \%DNA in head of comet along with a decrease in the mean values of comet length, tail length, tail moment and \%DNA in tail suggesting the protective abilities of EDME against the $\mathrm{CCl}_{4}$ induced DNA damages. Treatment of EDME to $\mathrm{CCl}_{4}$ intoxicated rats substantially inhibited the migration of DNA from head to tail in comet of hepatocytes. At lower dose of EDME $(200 \mathrm{mg} / \mathrm{kg})$ there was $9.75 \%$ DNA migration from head to tail while 5.07\% DNA migration from head to tail of comet was recorded at higher dose of EDME $(400 \mathrm{mg} / \mathrm{kg})$ suggesting the toxico-suppressive effect of EDME.

Number of DNA strand breaks (tail moment -1) provides a useful estimate for the protective abilities of the extract. Generation of ROS is considered to be involved in the oxidative DNA damages. In this investigation DNA strand breaks were not determined in the control group as well as the groups treated with EDME alone at both $200 \mathrm{mg} / \mathrm{kg}$ and $400 \mathrm{mg} / \mathrm{kg}$ treatment to rats. However, treatment of $\mathrm{CCl}_{4}$ to rats caused 9.48 number of DNA strand breaks in the comet of hepatocytes. The coadministration of EDME to $\mathrm{CCl}_{4}$ treated rats decreased the number of DNA stand breaks; $1.64(200 \mathrm{mg} / \mathrm{kg})$ and $0.181(400 \mathrm{mg} / \mathrm{kg})$ of EDME, respectively. DNA strand breaks were not recorded with the co-administration of silymarin to $\mathrm{CCl}_{4}$ intoxicated rats. These results suggested that EDME is effective in decreasing the ROS level, DNA fragmentation and in increasing the cell viability. DNA damaging effects of $\mathrm{CCl}_{4}$ might be ameliorated by the various phytochemical classes reported in $E$. dracunculoides [19]. Protection of DNA damages induced with hydrogen peroxide in human lymphocytes has been demonstrated with various herbal extracts [40].

The histology of the liver is the direct mean of assessing the protective effects of therapeutic agents against $\mathrm{CCl}_{4}$ induced hepatic damages. $\mathrm{CCl}_{4}$ induced the high degree of damage in liver cells, by inducing fibrosis, necrosis, cellular hypertrophy and central lobule disruption. Co-administration of silymarin as well as low and high dose of EDME ameliorated the toxic effects of $\mathrm{CCl}_{4}$ and decreased the damages induced with $\mathrm{CCl}_{4}$ intoxication. The results of this study are in accordance with previous reports [41]. The protective effects exhibited by the EDME might be attributed by the presence of flavonoids, terpenoids, sterols and tannins. E. dracunculoides was found to be constituted by rutin, catechin, myricetin and caffeic acid [19].

\section{Conclusions}

Our study recommends that E. dracunculoides have the aptitude to ameliorate the hepatic damage provoked by $\mathrm{CCl}_{4}$ and has potential to restore the levels 
of enzyme activity, serum markers, DNA damages and histopathological amendments. The defensive properties of EDME might probably be concomitant with its phytochemical profile and antioxidant properties.

\author{
Abbreviations \\ ALP: Alkaline phosphatase; ALT: Alanine transaminase; AST: Aspartate \\ transaminase; CAT: Catalase; EDME: Euphorbia dracunculoides methanol \\ extract; GSH: Reduced glutathione; GST: Glutathione-S-transferase; \\ POD: Peroxidase; SOD: Superoxide dismutase; TBARS: Thiobarbituric acid \\ reactive substances
}

\section{Acknowledgements}

MRK is intensely acknowledged for his kind supervision, expert guidance and substantial facilitations of all necessary materials and equipment.

\section{Funding}

The project was funded by the Department of Biochemistry Quaid-i-Azam University Islamabad Pakistan.

\section{Availability of data and materials}

All the data is contained in the manuscript.

\section{Authors' contributions}

RB made significant contribution to experimentation, acquisition and drafting of the manuscript. MRK has made substantial contribution to designing, analyzing and drafting of the manuscript. MM made a contribution in the experimentation and acquisition of the data. All authors read and approved the final manuscript.

\section{Authors' information}

MRK did his Diploma in Unani Medicine and Surgery (DUMS) and is a registered practitioner of the National Council for Tibb of Pakistan. He is working as Associate Professor at the Department of Biochemistry, Quaid-iAzam University, Islamabad, Pakistan.

\section{Competing interest}

The authors declare that they have no competing interests.

\section{Consent for publication}

Not applicable.

Ethics approval and consent to participate

This study makes use of rats and the experimental protocol for the use of animal was approved (Bch\#0267) by the ethical board of Quaid-i-Azam University, Islamabad Pakistan.

\section{Publisher's Note}

Springer Nature remains neutral with regard to jurisdictional claims in published maps and institutional affiliations.

\section{Author details}

'Department of Biochemistry, Faculty of Biological Sciences, Quaid-i-Azam University, Islamabad 45320, Pakistan. ${ }^{2}$ Department of Pharmacy, Faculty of Biological Sciences, Quaid-i-Azam University, Islamabad 45320, Pakistan.

Received: 15 December 2016 Accepted: 13 April 2017

Published online: 20 April 2017

\section{References}

1. Gutteridge J. Lipid peroxidation and antioxidants as biomarkers of tissue damage. Clin Chem. 1995;41(12):1819-28.

2. Tirkey N, Pilkhwal S, Kuhad A, Chopra K. Hesperidin, a citrus bioflavonoid, decreases the oxidative stress produced by carbon tetrachloride in rat liver and kidney. BMC Pharmacol. 2005;5(1):2.

3. Kasprzak KS. Oxidative DNA and protein damage in metal-induced toxicity and carcinogenesis 1, 3. Free Radic Biol Med. 2002;32(10):958-67.

4. Jacob RA, Sotoudeh G. Vitamin C function and status in chronic disease. Nutr Clin Care. 2002;5(2):66-74.
5. Hernández-muñoz R, Díaz-muñoz M, Suárez J, de Sánchez VC. Adenosine partially prevents cirrhosis induced by carbon tetrachloride in rats. Hepatology. 1990;12(2):242-8.

6. Dimitrios B. Sources of natural phenolic antioxidants. Trends Food Sci Technol. 2006;17(9):505-12.

7. Torel J, Cillard J, Cillard P. Antioxidant activity of flavonoids and reactivity with peroxy radical. Phytochemistry. 1986;25(2):383-5.

8. Husain SR, Cillard J, Cillard P. Hydroxyl radical scavenging activity of flavonoids. Phytochemistry. 1987;26(9):2489-91.

9. Robak J, Gryglewski RJ. Flavonoids are scavengers of superoxide anions. Biochem Pharmacol. 1988;37(5):837-41.

10. Perveen A, Qaiser M. Pollen flora of Pakistan-XLVII. Euphorbiaceae. Pak J Bot. 2005;37(4):785.

11. Jassbi AR. Chemistry and biological activity of secondary metabolites in Euphorbia from Iran. Phytochemistry. 2006;67(18):1977-84.

12. Wang L, Cao P, Zang Z, Ma Y-T, Liu F-Y, Li F, WU X-H, Huang S-X, Zhao Y. Two new triterpene rhamnosides from Euphorbia dracunculoides lam. Phytochem Lett. 2015;12:168-72.

13. Sikarwar R, Bajpai A, Painuli R. Plants used as veterinary medicines by aboriginals of Madhya Pradesh, India. Pharm Biol. 1994;32(3):251-5.

14. Mossa JS, Al-Yahya MA, Al-Meshal IA: Medicinal plants of Saudi Arabia. 1987.

15. Sharma J, Painuli R, Gaur R. Plants used by the rural communities of district Shahjahanpur, Uttar Pradesh. Indian J Tradit Knowl. 2010;9(4):798-803.

16. Ito M, Shimura H, Watanabe N, Tamai M, Hanada K, Takahashi A, Tanaka Y, Arai K, Zhang PL, Chang R. Hepatoprotective compounds from Canarium album and Euphorbia nematocypha. Chem Pharm Bull (Tokyo). 1990;38(8):2201-3.

17. Bigoniya P, Rana AC. Protective effect of Euphorbia neriifolia saponin fraction on $\mathrm{CCl}_{4}$-induced acute hepatotoxicity. Afr J Biotechnol. 2010;8:7148-56.

18. Aamir S, Tippeswamy BS, Kulkarni VH, Karunakar H. Hepatoprotective effects of Euphorbia thymifolia whole plant extract on $\mathrm{CCl}_{4}$ induced hepatic damages in rats. Int J Res Ayurveda Pharm. 2011;2:681-6.

19. Majid M, Khan MR, Shah NA, Haq IU, Farooq MA, Ullah S, Sharif A, Zahra Z, Younis T, Sajid M. Studies on phytochemical, antioxidant, anti-inflammatory and analgesic activities of Euphorbia dracunculoides. BMC Complement Altern Med. 2015;15(1):1.

20. Shyu M-H, Kao T-C, Yen G-C. Hsian-tsao (Mesona procumbens Heml.) prevents against rat liver fibrosis induced by $\mathrm{CCl}_{4}$ via inhibition of hepatic stellate cells activation. Food Chem Toxicol. 2008;46(12):3707-13.

21. Chance B, Maehly A. [136] assay of catalases and peroxidases. Methods Enzymol. 1955;2:764-75.

22. Kakkar P, Das B, Viswanathan P. A modified spectrophotometric assay of superoxide dismutase. Indian J Biochem Biophys. 1984;21(2):130-2.

23. Habig WH, Pabst MJ, Jakoby WB. Glutathione S-transferases the first enzymatic step in mercapturic acid formation. J Biol Chem. 1974; 249(22):7130-9.

24. Jollow D, Mitchell J. Zampaglione Na, Gillette J: Bromobenzene-induced liver necrosis. Protective role of glutathione and evidence for 3, 4bromobenzene oxide as the hepatotoxic metabolite. Pharmacology. 1974; 11(3):151-69.

25. labal M, Sharma S, Rezazadeh H, Hasan N, Abdulla M, Athar M. Glutathione metabolizing enzymes and oxidative stress in ferric nitrilotriacetate mediated hepatic injury. Redox Rep. 1996;2(6):385-91.

26. Lowry OH, Rosebrough NJ, Farr AL, Randall RJ. Protein measurement with the Folin phenol reagent. J Biol Chem. 1951;193(1):265-75.

27. Pick E, Keisari Y. Superoxide anion and hydrogen peroxide production by chemically elicited peritoneal macrophages-induction by multiple nonphagocytic stimuli. Cell Immunol. 1981;59(2):301-18.

28. Grisham MB, Johnson GG, Lancaster JR. Quantitation of nitrate and nitrite in extracellular fluids. Methods Enzymol. 1996;268:237-46.

29. Dhawan A, Bajpayee M, Parmar D. Comet assay: a reliable tool for the assessment of DNA damage in different models. Cell Biol Toxicol. 2009; 25(1):5-32.

30. Rashid U, Khan MR, Sajid M. Hepatoprotective potential of Fagonia Olivieri DC. Against acetaminophen induced toxicity in rat. BMC Complement Altern Med. 2016;16:449.

31. Rashid U, Khan MR. Fagonia olivieri prevented hepatorenal injuries induced with gentamicin in rat. Biomed Pharmacother. 2017;2017(88):469-79.

32. Schmilovitz-Weiss H, Tovar A, Halpern M, Sulkes J, Braun M, Rotman Y, TurKaspa R, Ben-Ari Z. Predictive value of serum globulin levels for the extent of hepatic fibrosis in patients with chronic hepatitis B infection. J Viral Hepat. 2006;13(10):671-7. 
33. Younis T, Khan MR, Sajid M. Protective effects of Fraxinus xanthoxyloides (wall.) leaves against $\mathrm{CCl}_{4}$ induced hepatic toxicity in rat. BMC Complement Altern Med. 2016;16:407.

34. Sajid M, Khan MR, Shah NA, Shah SA, Ismail H, Younis T, Zahra Z.

Phytochemical, antioxidant and hepatoprotective effects of Alnus nitida bark in carbon tetrachloride challenged Sprague Dawley rats. BMC Complement Altern Med. 2016;16:268.

35. Khan RA, Khan MR, Khan A. Comparative antioxidant scavenging and lipid peroxidation activity of rutin and gallic acid. Bangladesh J Pharmacol. 2015;10: 637-8.

36. Louis H, Laethem J-LV WW, Quertinmont E, Degraef C, Berg KVD, Demols A Goldman M, Moine OL, Deviere J. Interleukin-10 controls neutrophilic infiltration, hepatocyte proliferation, and liver fibrosis induced by carbon tetrachloride in mice. Hepatology. 1998;28(6):1607-15.

37. Natsume M, Tsuji H, Harada A, Akiyama M, Yano T, Ishikura H, Nakanishi I, Matsushima K, Kaneko S, Mukaida N. Attenuated liver fibrosis and depressed serum albumin levels in carbon tetrachloride-treated IL-6-deficient mice. J Leukoc Biol. 1999;66(4):601-8.

38. Parola M, Robino G. Oxidative stress-related molecules and liver fibrosis. J Hepatol. 2001;35(2):297-306.

39. Sajid M, Khan MR, Shah NA, Ullah S, Younis T, Majid M, Ahmad B, Nigussie D. Proficiencies of Artemisia scoparia aagainst $\mathrm{CCl}_{4}$ induced DNA damages and renal toxicity in rat. BMC Complement Altern Med. 2016;16:149.

40. Lin $\mathrm{K}-\mathrm{H}$, Yang $\mathrm{Y}-\mathrm{Y}$, Yang C-M, Huang M-Y, Lo H-F, Liu K-C, Lin H-S, Chao P-Y. Antioxidant activity of herbaceous plant extracts protect against hydrogen peroxide-induced DNA damage in human lymphocytes. BMC Res Notes. 2013;6:490.

41. Alkreathy HM, Khan RA, Khan MR, Sahreen S. $\mathrm{CCl}_{4}$ induced genotoxicity and DNA oxidative damages in rats; hepatoprotective effect of Sonchus arvensis. BMC Complement Altern Med. 2014;14:452.

\section{Submit your next manuscript to BioMed Central and we will help you at every step:}

- We accept pre-submission inquiries

- Our selector tool helps you to find the most relevant journal

- We provide round the clock customer support

- Convenient online submission

- Thorough peer review

- Inclusion in PubMed and all major indexing services

- Maximum visibility for your research

Submit your manuscript at www.biomedcentral.com/submit 